\section{4. 結㪴}

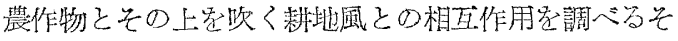
の最初の段骝として, 著者等は耕地風の䞍造に關する間 題の所在考时らかにすると共に, 关れに閣する實際的な

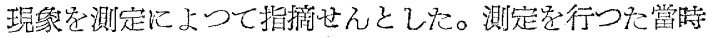

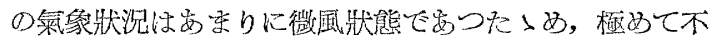
十分な測定結果しか得られなかつたが，稻田上に風が特

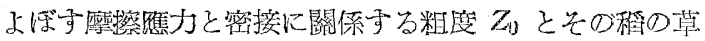
高 $h$ との閣係としては

$$
\alpha=\frac{h}{Z_{\mathrm{J}}} \doteq 4 .
$$

が得られた。この比例係數については過去20年間にわた

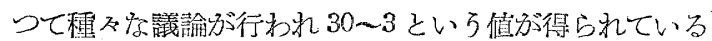
が，著者等の結果は關東東山硔業試羷場の稻田といら特

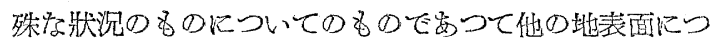
いてのものと蚛必ずれも一致する必要はない上万思市 れる。併しいずれとしてる $Z_{0}$ 孛障碍物の高导 hだけで表

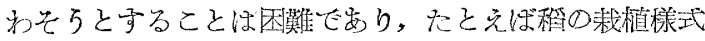
のよらな陵碍物の幾何學的な形狀とその配列にる閣係す
るタのと考它られる。

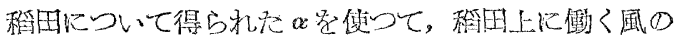

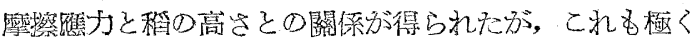

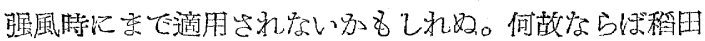
の表偭ほ海面に生ずる波と同じように風速によつて著し くその形究變えるととが考えられるからだる。

本報でほ重要な問題の大部分党後に戣しているが，乙

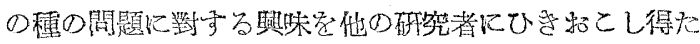
ならば著者等の幸とする所て㑒る。

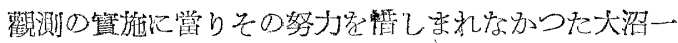

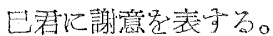

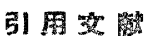

Halstead, M. 1951 Suppl. Inter. Rep. No. 14, Lab. Climatol. Johns Hopkins Univ.

Inoue, E. 1951 憵朋力學，4, 53.

Lettau, H. 1949 Geophysical Research Paper, Air Force Cambridge Research Laboratories, No. 1.

Lettar, H. 1939 Atmosphärische Turbulenz, Berlin Munk, W.H. 1951 To be published.

Paeschke,W. 1938 Eeitr. Z. Phys. fr. Atm., 24, 163.

Takeda, K. 1949 氣象集誌, 27, 333.

\title{
Résumé
}

Vertical distributions of wind velocity over a rice field of the average foliageheight of ca. $80 \mathrm{~cm}$ wer observed at 6 positions of heignts from $84 \mathrm{~cm}$ to $604 \mathrm{~cm}$.

For light winds the vertical velocity distribution was found to be fitted to the logarithmic law fairly well, and the roughness parameter $Z_{0}$ was obtained as ca. $18 \mathrm{~cm}$. Considering two series of observation, $Z_{0}$ is found to be approximately a quarter of foliage-height of rice.

\section{害 贈 圆 畫}

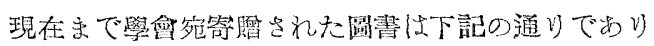
ます。誌上起借りて謝意起変与こ同時に會員の御利用 起方愿いいたしき导。

林䉥技少 No. 117, 118 日本林業技術協會

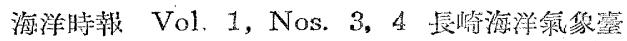

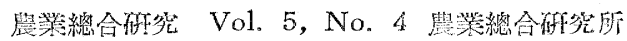
日本監學會誌 Vol.5, No. 6 日本敬學會

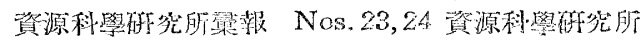
Hilgardia Vol. 21 Nos. 1 7

University of California

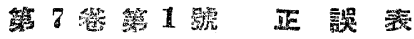

\begin{tabular}{|c|c|c|c|}
\hline 埧 & 位 㷂 & 部 & 正 \\
\hline 27 & 在本交下施 & 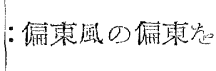 & : 僱東風の偏向先 \\
\hline 29 & 左 1 行日 & $\bar{x}$ 附近加b & $\bar{x}=0^{\circ}$ 附近加 \\
\hline$"$ & 左 10 行日 & $\begin{array}{r}\text { 中心こしで } \\
\text { 左石に }\end{array}$ & 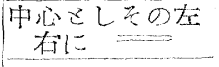 \\
\hline$" \prime$ & 右 17 行且 & 漏莫に近い & 真真に近い \\
\hline
\end{tabular}

